\title{
Sensing Organic Amines and Quantitative Monitoring Intracellular pH Change Using Fluorescent Self-Assembly System
}

\author{
Xinhua $\mathrm{Cao}^{* a}$, Yiran $\mathrm{Li}^{\mathrm{a}}$, Aiping $\mathrm{Gao}^{\mathrm{a}}$, Yongsheng $\mathrm{Yu}^{\mathrm{a}}$, Xueping Chang ${ }^{\mathrm{a}}, \mathrm{Xiaohan}_{\mathrm{Hei}}{ }^{\mathrm{b}}$ \\ ${ }^{a}$ College of Chemistry and Chemical Engineering \& Henan Province Key laboratory of Utilization of Non-metallic \\ Mineral in the South of Henan, Institute for Conservation and Utilization of Agro-bioresources in Dabie \\ Mountains, Xinyang Normal University, Xinyang 464000,China E-mail:caoxhchem@163.com \\ ${ }^{b}$ College of municipal and environmental engineering, Henan University of Urban Construction, Pingdingshan \\ 467000, China
}

\section{Experimental Section}

Reagents and materials: 3-Hydroxy-1,8-naphthalic anhydride was purchased from shanghai Titan technology Co., Ltd. Butylamine, dodecanamine and octadecylamine were provided from reagent company. All other reagents were analytically pure.

Gelation test: The detailed gelation process was the same as that of the previous references ${ }^{17,30}$.

Cells culture and imaging: HepG2 cells were cultured in Dulbecco's modified Eagle medium (DMEM) containing $10 \%$ fetal bovine serum and $1 \%$ antibiotic-antimycotic at $37{ }^{\circ} \mathrm{C}$ in a $5 \%$ $\mathrm{CO}_{2} / 95 \%$ air incubator. Fluorescence imaging, cells $\left(4 \times 10^{3}\right.$ per well) were passed on confocal dishes and incubated for $24 \mathrm{~h}$. Before the staining experiments, the cells were washed twice with PBS.

Cell viability: Cytotoxicity was assessed by performing CCK8 assay on the HepG2 cells. Cells were seeded into a 96 -well plate at $2 \times 10^{3} /$ well and were cultured at $37^{\circ} \mathrm{C}$ and $5 \% \mathrm{CO}_{2}$ for $24 \mathrm{~h}$. Different concentrations of $\mathbf{N}-4(0,1,2.5,5,7.5$ and $10 \mu \mathrm{M})$ were then added to the wells. After incubation for 5 or $10 \mathrm{~h}, \mathrm{CCK} 8(0.5 \mathrm{mg} / \mathrm{mL})$ was added to each well and the plate was incubated for $1 \mathrm{~h}$. The optical densities at $490 \mathrm{~nm}$ were measured.

Instrumentation conditions: the detail instrumentation conditions were the same as that of the previous references ${ }^{17,30}$. 


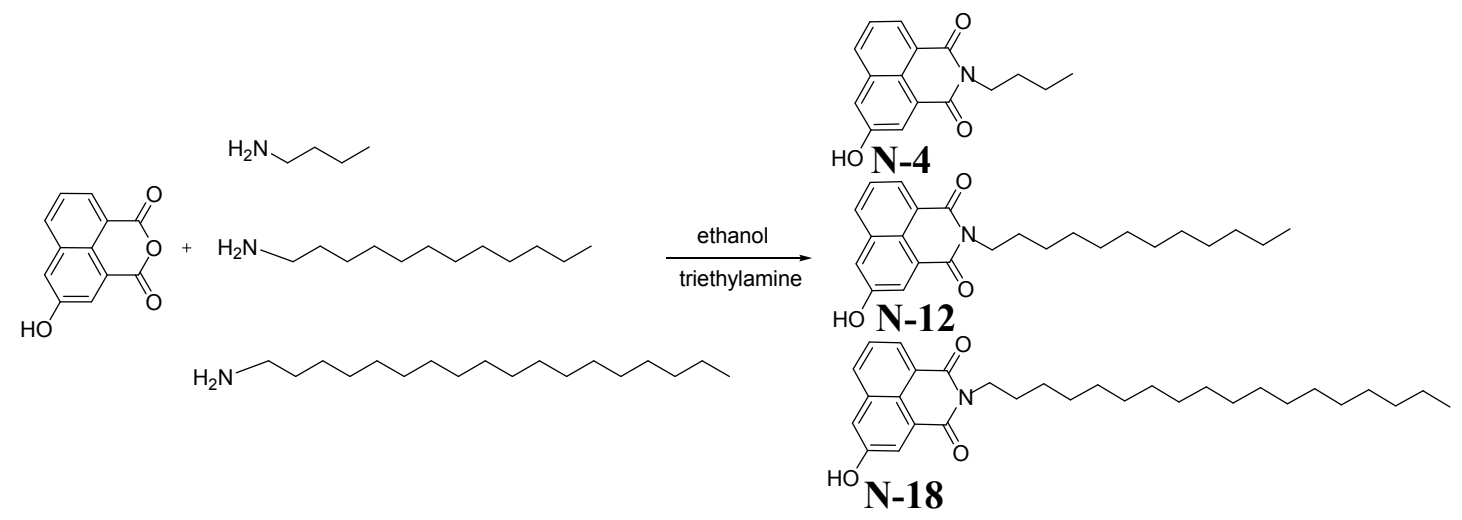

Scheme 1 Synthetic route of compounds N-4, N-12 and N-18.

Compounds N-4, N-12 and N-18 were synthesized according to literature 1.

Synthesis of N-4: 3-hydroxyl-1,8-Naphthalimide (1.0 g, $4.67 \mathrm{mmol})$, n-Butylamine ( $0.41 \mathrm{~g}$, $5.60 \mathrm{mmol})$ and triethylamine $(5 \mathrm{~mL})$ were mixed in ethanol $(20 \mathrm{~mL})$. The reaction mixture was heated for refluxing and stirred for $12 \mathrm{~h}$ under a nitrogen atmosphere. After the reaction was over, large amount of solvent was removed under reduced pressure, and the residue was filtrated and washed with cold ethanol for three times. The compound $\mathbf{N}-\mathbf{4}$ as a yellow powder was obtained with the yield of $65 \% ;{ }^{1} \mathrm{HNMR}\left(400 \mathrm{MHz}, \mathrm{CDCl}_{3}\right): \delta 8.44(\mathrm{~d}, J=7.6 \mathrm{~Hz}, 1 \mathrm{H}), 8.31(\mathrm{~d}, J=2.4 \mathrm{~Hz}$, 1H), $8.06(\mathrm{t}, J=7.6 \mathrm{~Hz}, 1 \mathrm{H}), 7.68(\mathrm{t}, J=7.6 \mathrm{~Hz}, 1 \mathrm{H}), 7.58(\mathrm{~d}, J=2.4 \mathrm{~Hz}, 1 \mathrm{H}), 6.49(\mathrm{~s}, 1 \mathrm{H}), 4.18$ $(\mathrm{t}, J=7.6 \mathrm{~Hz}, 2 \mathrm{H}), 1.72(\mathrm{~m}, 2 \mathrm{H}), 1.47(\mathrm{~m}, 2 \mathrm{H}), 0.98(\mathrm{t}, J=7.2 \mathrm{~Hz}, 3 \mathrm{H}) ;{ }^{13} \mathrm{CNMR}(100 \mathrm{MHz}$, $\left.\mathrm{CDCl}_{3}\right): \delta 164.4,155.1,133.4,132.5,128.9,127.5,116.3,40.4,30.2,20.4,13.8$. HRMS calculated for $\mathrm{C}_{16} \mathrm{H}_{16} \mathrm{NO}_{3}[\mathrm{M}+\mathrm{H}]^{+}$270.1130, found: 270.1133 .

Synthesis of N-12: The synthesis procedure was the same as $\mathbf{N}-4$. The brown product $\mathbf{N}-12$ was obtained with the yield of $72 \%$; ${ }^{1} \mathrm{HNMR}\left(400 \mathrm{MHz}, \mathrm{CDCl}_{3}\right): \delta 8.42(\mathrm{~d}, J=7.6 \mathrm{~Hz}, 1 \mathrm{H}), 8.38(\mathrm{~d}, J$ $=2.4 \mathrm{~Hz}, 1 \mathrm{H}), 8.04(\mathrm{~d}, \mathrm{~J}=7.6 \mathrm{~Hz}, 1 \mathrm{H}), 7.66(\mathrm{t}, J=7.6 \mathrm{~Hz}, 1 \mathrm{H}), 7.58(\mathrm{~d}, J=2.4 \mathrm{~Hz}, 1 \mathrm{H}), 4.17(\mathrm{t}, J$ $=7.6 \mathrm{~Hz}, 2 \mathrm{H}), 1.73(\mathrm{~m}, 2 \mathrm{H}), 1.42-1.24(\mathrm{~m}, 18 \mathrm{H}), 0.87(\mathrm{t}, J=7.2 \mathrm{~Hz}, 3 \mathrm{H}) ;{ }^{13} \mathrm{CNMR}(100 \mathrm{MHz}$, $\left.\mathrm{CDCl}_{3}\right): \delta 164.5,164.3,155.2,133.4,132.6,128.8,127.4,123.8,123.4,122.4,116.5,40.8,31.9$, 29.6, 29.4, 29.3, 28.1, 27.2, 22.7, 14.1; HRMS calculated for $\mathrm{C}_{24} \mathrm{H}_{32} \mathrm{NO}_{3}[\mathrm{M}+\mathrm{H}]^{+}$382.2382, Found: 382.2364 .

Synthesis of N-18: The synthesis procedure was the same as $\mathbf{N}-4$. The brown product $\mathbf{N - 1 8}$ was obtained with the yield of $83 \%$; ${ }^{1} \mathrm{HNMR}\left(400 \mathrm{MHz}, \mathrm{CDCl}_{3}\right): \delta 8.43(\mathrm{~d}, J=7.6 \mathrm{~Hz}, 1 \mathrm{H}), 8.34(\mathrm{~d}, J$ $=2.4 \mathrm{~Hz}, 1 \mathrm{H}), 8.05(\mathrm{~d}, J=7.6 \mathrm{~Hz}, 1 \mathrm{H}), 7.67(\mathrm{~d}, J=7.6 \mathrm{~Hz}, 1 \mathrm{H}), 7.58(\mathrm{~d}, J=2.4 \mathrm{~Hz}, 1 \mathrm{H}), 4.17(\mathrm{t}$, $J=7.6 \mathrm{~Hz}, 2 \mathrm{H}), 1.73(\mathrm{~m}, 2 \mathrm{H}), 1.42-1.24(\mathrm{~m}, 30 \mathrm{H}), 0.87(\mathrm{t}, J=7.2 \mathrm{~Hz}, 3 \mathrm{H}) ;{ }^{13} \mathrm{CNMR}(100 \mathrm{MHz}$, 
$\left.\mathrm{CDCl}_{3}\right): \delta 164.3,155.0,133.4,132.5,128.8,127.4,124.0,123.5,122.5,122.4,116.4,40.7,31.9$, 29.7, 29.6, 29.4, 28.1, 27.2, 22.7, 14.1; HRMS calculated for $\mathrm{C}_{30} \mathrm{H}_{44} \mathrm{NO}_{3}[\mathrm{M}+\mathrm{H}]^{+}$466.3321, Found: 466.3330 .
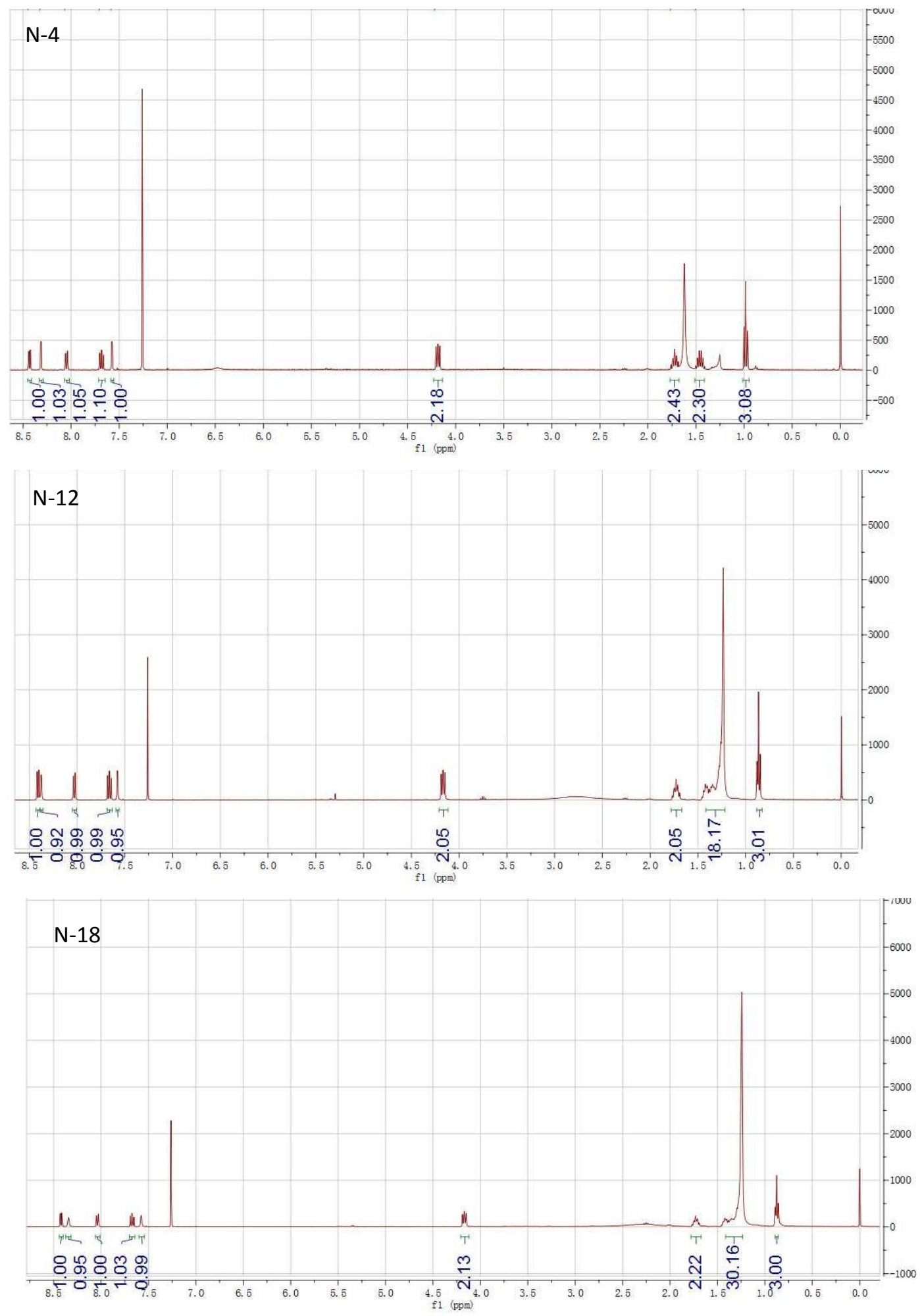

Fig. S1 ${ }^{1} \mathrm{HNMR}$ spectra of $\mathbf{N}-4, \mathbf{N}-12$ and $\mathbf{N}-18$ in $\mathrm{CDCl}_{3}$. 


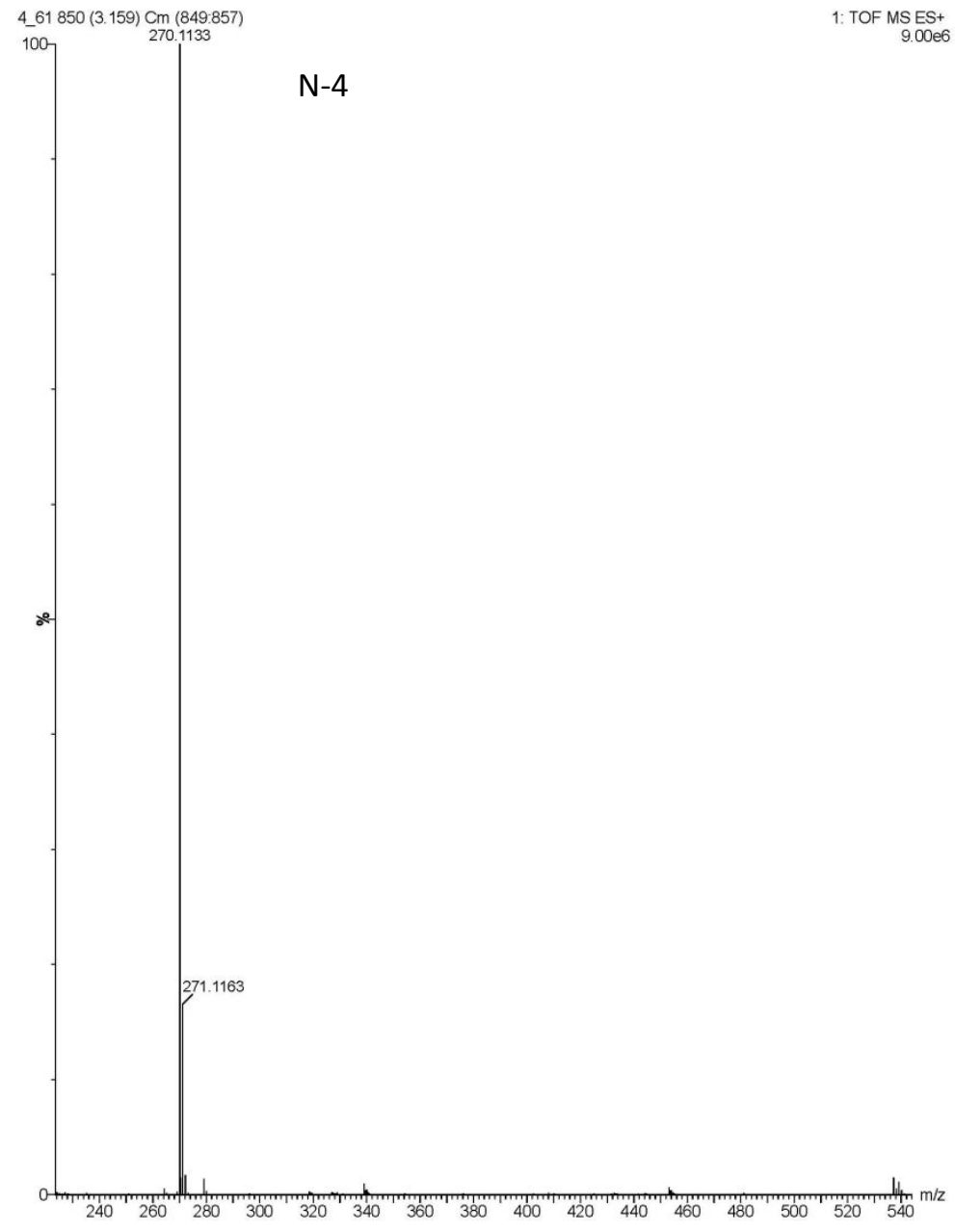




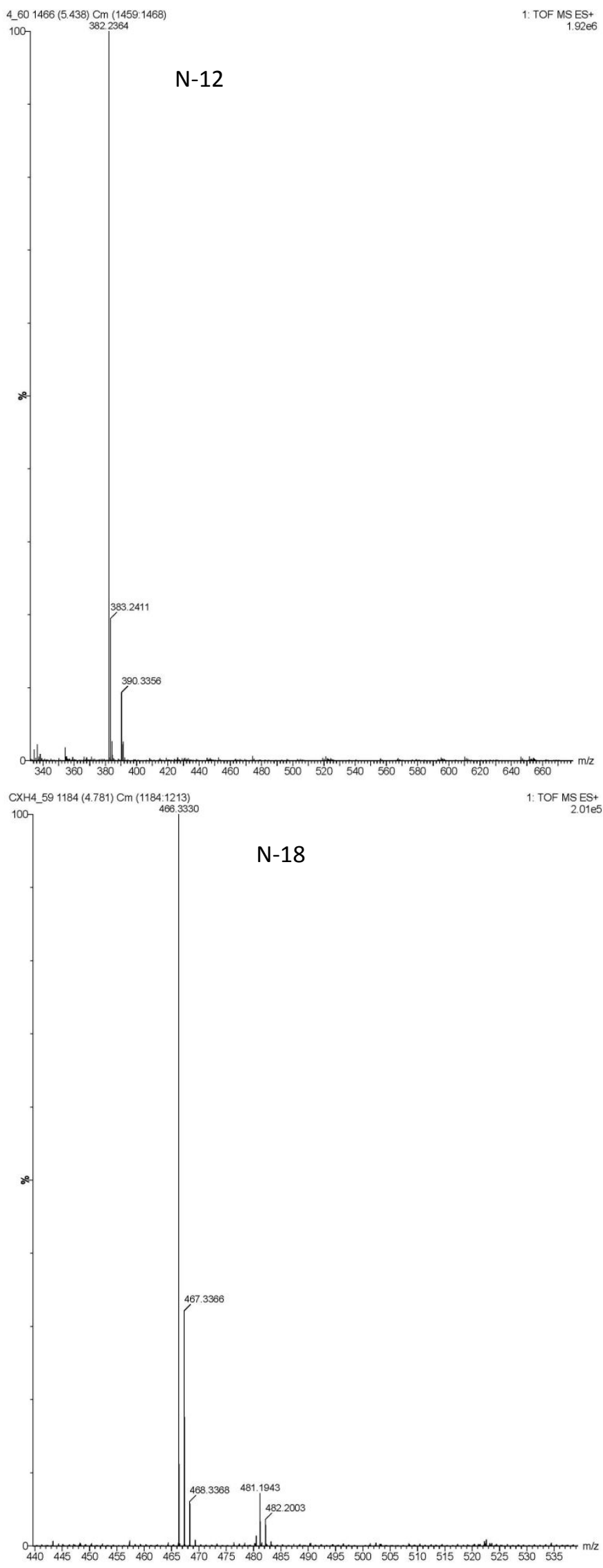

Fig. S2 HRMS spectra of N-4, N-12 and N-18. 
Table S1 EDX experimental results of xerogels N-18 from different solvents.

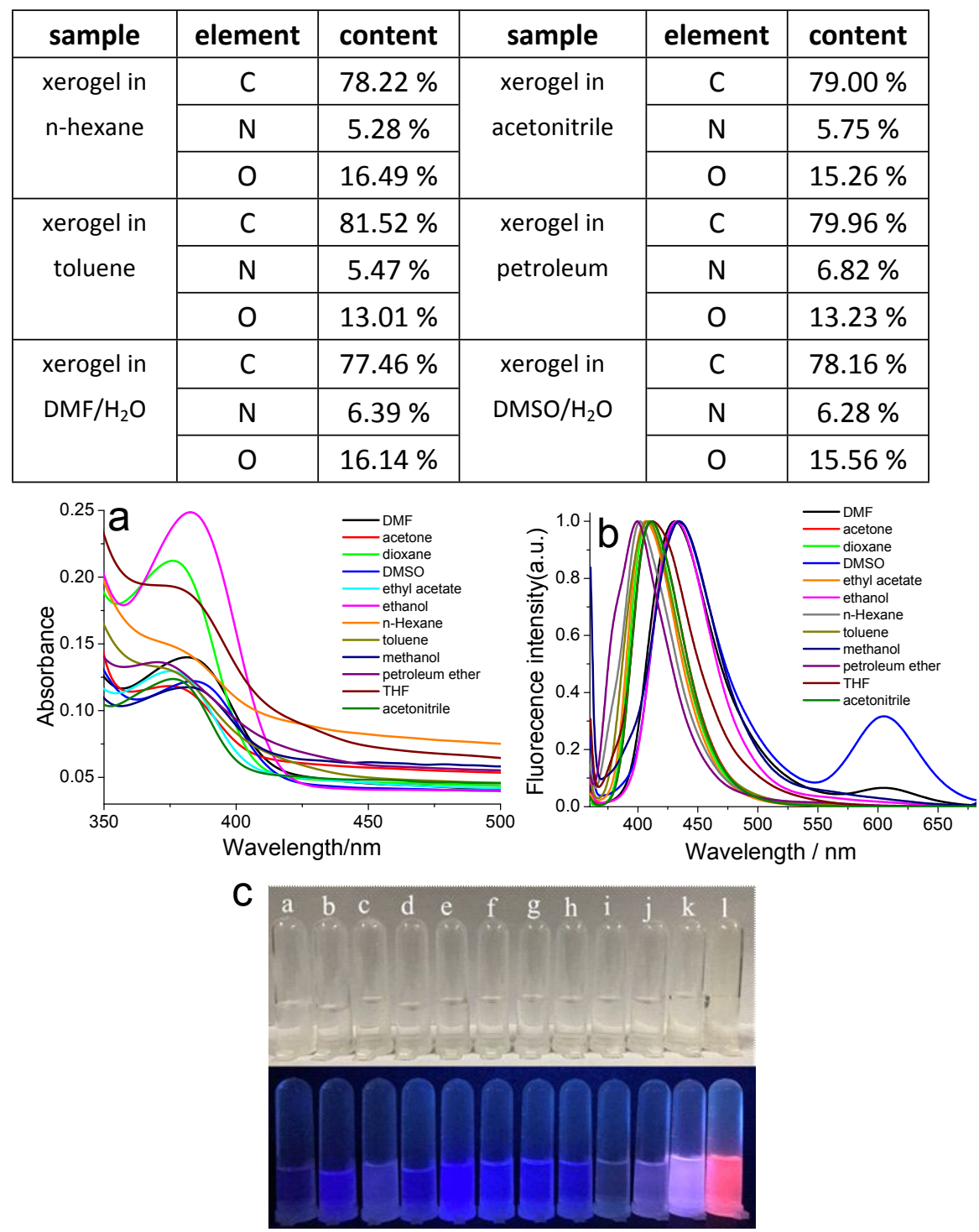

Fig. S3 a) UV-vis absorption spectra of N-18 in different solvents; b) Fluorescence emission spectra of N-18 in different solvents; c) The images of N-18 solutions in different solvents; a) for petroleum ether; b) for n-hexane; c) for acetonitrile; d) ethyl acetate; e) for 1,4-dioxane; f) for THF; g) for toluene; h) for acetone; i) for methanol; j) for ethanol; k) for DMF and l) for DMSO. The concentration of $\mathbf{N}-18$ solution was $10^{-5} \mathrm{M}$. 


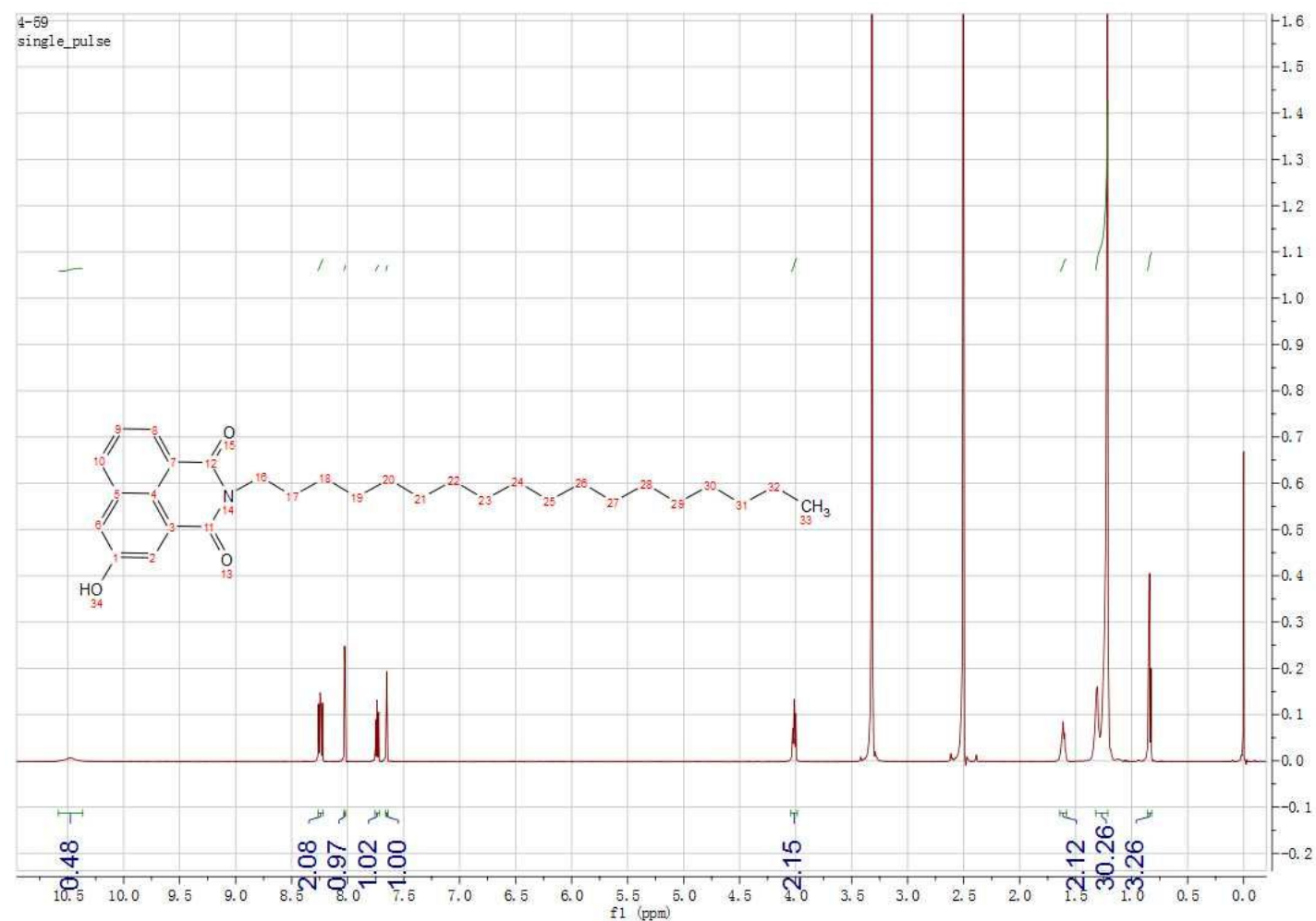

Fig. $\mathbf{S 4}{ }^{1} \mathrm{HNMR}$ spectrum of N-18 in DMSO-d
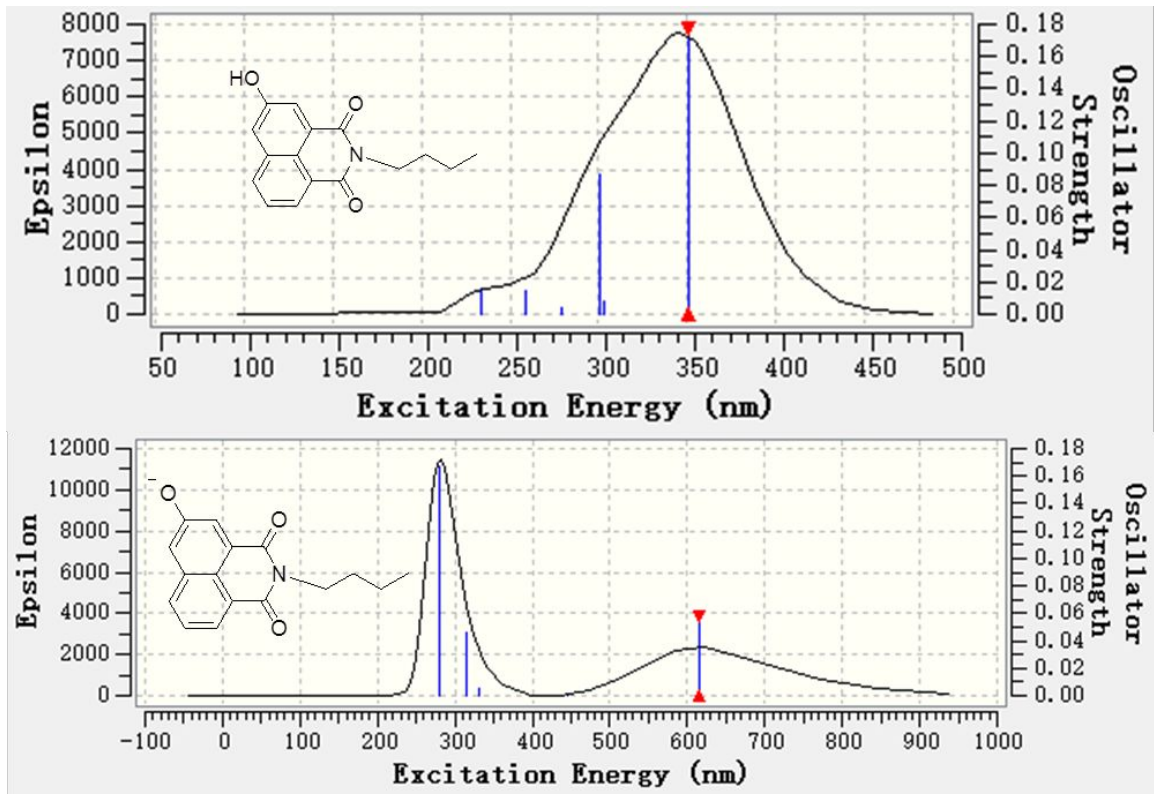

Fig. S5 The emission spectra of $\mathbf{N}-\mathbf{4}$ and deprotonated N-4 obtained from the DFT calculation. 

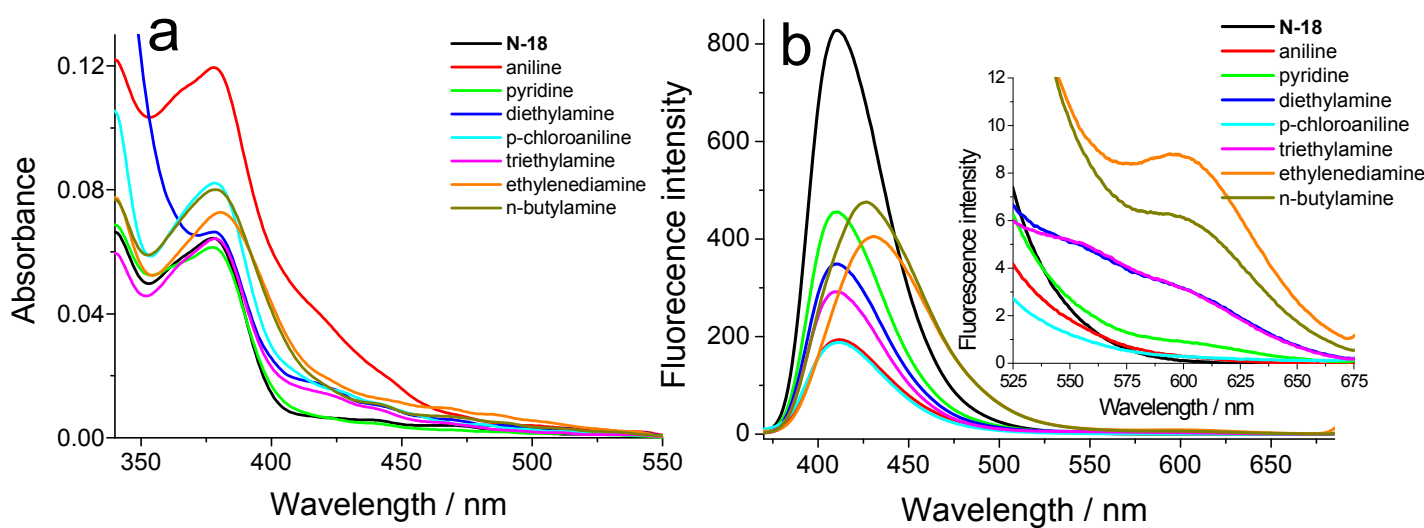

Fig. S6 UV-vis absorption (a) and fluorescence emission (b) change of N-18 acetonitrile solution (10 $\mu$ mol/L) under the addition of different amines. The addition amount of amines was $88 \mu \mathrm{L}$ of amine acetonitrile solution with the concentration of $1 \mathrm{M}$.

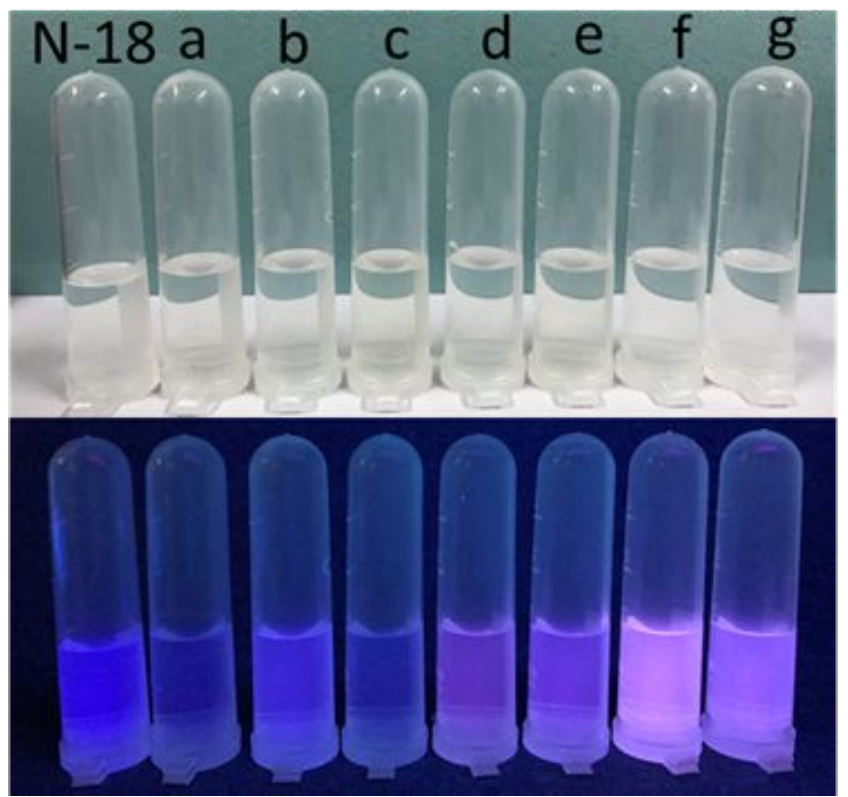

Fig. S7 Images of N-18 solution in acetonitrile with addition of different organic amines: a) for 4-chloroaniline; b) for pyridine; c) for aniline; d) for TEA; e) for diethylamine; f) for ethylenediamine; g) for n-butylamine. The uppers were under daylight. The lowers were under $365 \mathrm{~nm}$ light.

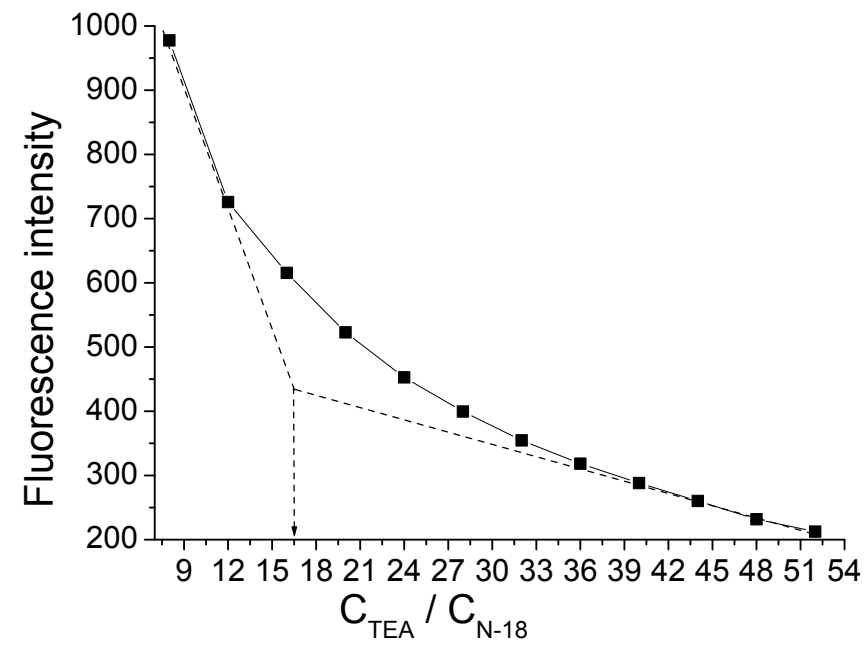

Fig. S8 Fluorescence intensity changes at $410 \mathrm{~nm}$ with different molar ratio of TEA and $\mathbf{N}-\mathbf{1 8}$ in acetonitrile. 


\section{Limit of detection calculation}

Table S2 Detection limit of compound N-18 toward TEA in acetonitrile by fluorescence intensity changes at 409 $\mathrm{nm}$

\begin{tabular}{|c|c|c|c|c|c|c|c|c|c|c|c|}
\hline $\mathrm{n}$ & 1 & 2 & 3 & 4 & 5 & 6 & 7 & 8 & 9 & 10 & 11 \\
\hline Intensity & 826.1 & 826.1 & 826.2 & 826.1 & 826.1 & 826.1 & 826.1 & 826.1 & 826.1 & 826.0 & 826.1 \\
\hline
\end{tabular}

The limit of detection (LOD) was determined with the following equation: $L O D=3 \sigma / b$. The $\sigma$ was the standard deviation of 11 blank samples $\left(10^{-5} \mathrm{M}\right.$ of $\left.\mathbf{N - 1 8}\right)$, and $b$ was the slope between the ratio of emission intensity versus TEA concentration.

$\mathrm{X}_{\text {average }}=826.1 \sigma_{\mathrm{wb}}=\operatorname{sqrt}\left(\sum\left(\mathrm{X}_{\mathrm{n}}-\mathrm{X}_{\text {average }}\right)^{2} / \mathrm{n}\right)=0.0018$

The detection limit: $[$ TEA $]=3 \sigma / b=2.23 \times 10^{-6} \mathrm{M}$

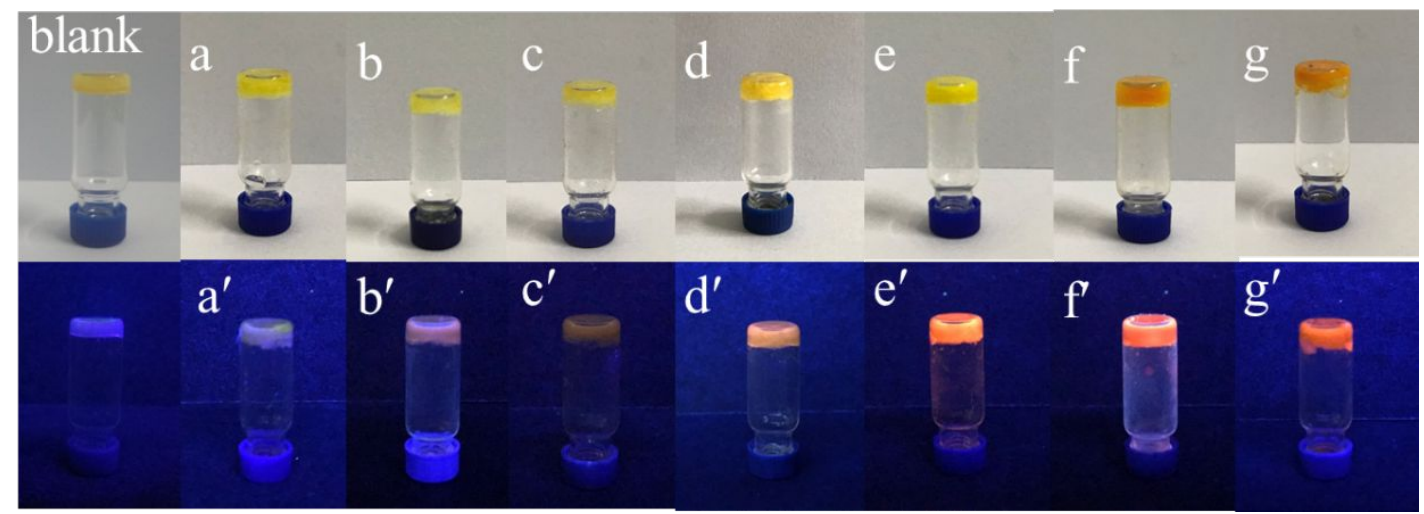

Fig. S9 Images of organogels N-18 in acetonitrile with addition of different organic amines: a) for 4-chloroaniline; b) for pyridine; c) for aniline; d) for TEA; e) for diethylamine; f) for ethylenediamine; g) for n-butylamine. The uppers were under daylight. The lowers were under $365 \mathrm{~nm}$ light.
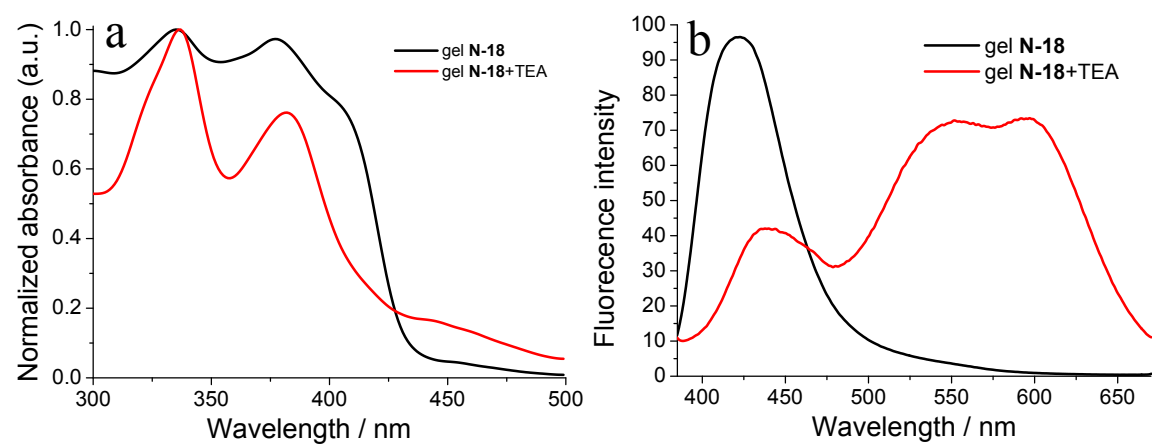

Fig. S10 UV-vis absorption (a) and fluorescence emission (b) change of organogel N-18 in acetonitrile before and after addition of TEA $(10 \mu \mathrm{L})$ 


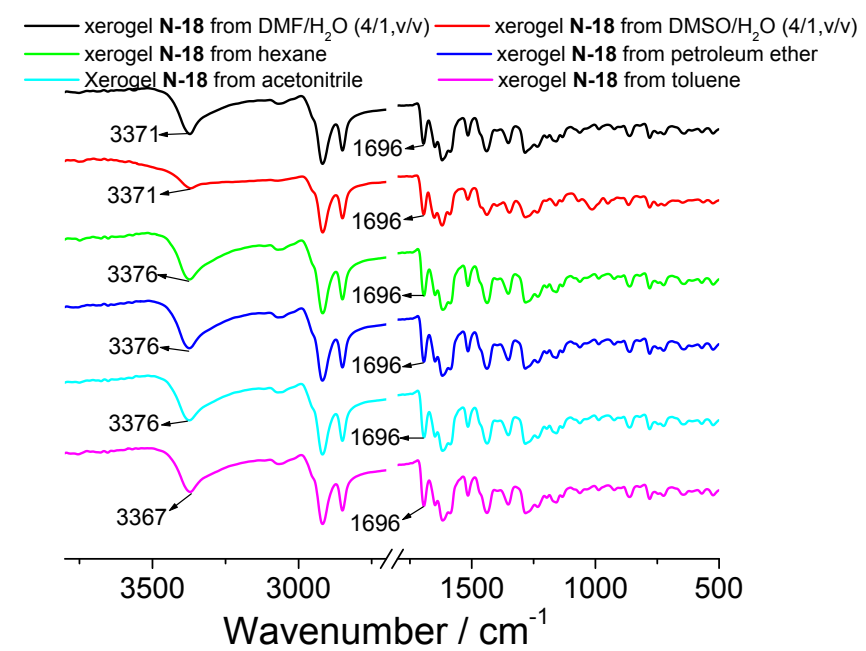

Fig. S11 FTIR spectra of xerogels N-18 from DMF/ $\mathrm{H}_{2} \mathrm{O}(4 / 1, \mathrm{v} / \mathrm{v}), \mathrm{DMSO} / \mathrm{H}_{2} \mathrm{O}(4 / 1, \mathrm{v} / \mathrm{v}), \mathrm{n}$-hexane, petroleum ether, acetonitrile and toluene.

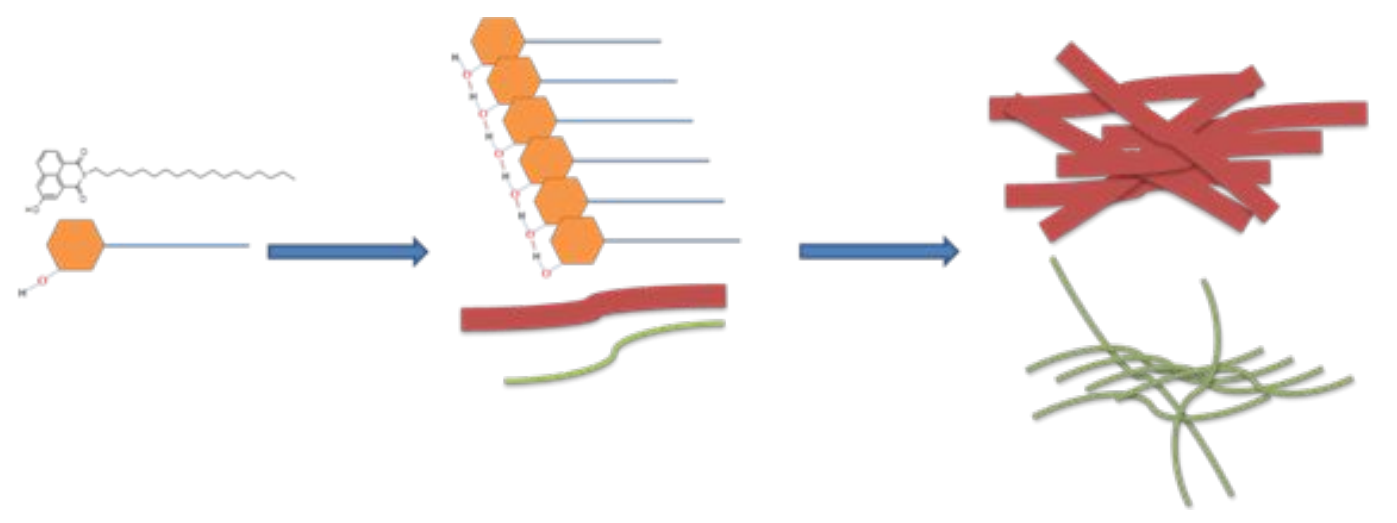

Fig. S12 The probable self-assembly mode of molecule $\mathbf{N}-\mathbf{1 8}$. 